\title{
Neuropsychiatry problem is not the chief clinical presentation of 2014 Western Africa Ebola virus infection
}

\section{Problemas neuropsiquiátricos não são a principal apresentação clínica da infecção pelos vírus Ebola em 2014 na África Ocidental}

Dear Sir,

The serious outbreak of the 2014 Western Ebola virus infection is the present global concern ${ }^{1,2,3}$. The high mortality rate and rapid extension of disease from its origin in West Africa to remote countries call for attention to properly manage the situation ${ }^{1,2,3}$. One of the difficulties in management of the infection is the limited knowledge on its clinical features. Basically, Ebola virus infection is a kind of viral infection that the main clinical presentation is febrile illness. There are also possibilities to have other additional clinical presentation. Here, the authors try to summarize on the magnitude of "neuropsychiatry problem" during clinical presentation. Of interest, based on available data from 15 confirmed cases reported from Guinea ${ }^{1,2,3,4}$, no case of patients with confirmed infection has the neuropsychiatry problem as the clinical presentation. In fact, the other viral hemorrhagic fever, such as dengue fever, can have "neuropsychiatry problem" as clinical presentation ${ }^{5}$. Nevertheless, based on present data, no "neuropsychiatry problem" during clinical presentation can be seen.

Beuy Joob $^{1}$, Viroj Wiwanitkit ${ }^{2}$

\section{References}

\footnotetext{
1. Green $\mathrm{A}$. WHO and partners launch Ebola response plan. Lancet 2014;384(9942):481. http://dx.doi.org/10.1016/S0140-6736(14)61322-2

2. Fletcher TE, Brooks TJ, Beeching NJ. Ebola and other viral haemorrhagic fevers. BMJ. 2014;349:5079. http://dx.doi.org/10.1136/bmj.g5079

3. Gostin LO, Lucey D, Phelan A. The Ebola epidemic: a global health emergency. JAMA. 2014;312(11):1095-6. http://dx.doi.org/10.1001/ jama.2014.11176
}

4. Baize S, Pannetier D, Oestereich L, Rieger T, Koivogui L, Magassouba $\mathrm{N}$ et al. Emergence of Zaire Ebola virus disease in Guinea. $N$ Engl J Med. 2014;371:1418-25. http://dx.doi.org/10.1056/ NEJMoa1404505

5.

Wiwanitkit S, Wiwanitkit V. Neurological complications in dengue infection. Arq Neuropsiquiatr. 2014;72(3):259. http://dx.doi.org/ 10.1590/0004-282X20130222 